\title{
THE REFORM OF CUSTOMS SYSTEM IN POLAND
}

The accession of Poland to the European Union has evoked the necessity of extending the force of the valid EU customs regulations into our territory. The Polish sovereignty in its normative sense has been passed in the range of customs to the EU with few exceptions ${ }^{1}$, but the sovereignty in its executive sense has stayed within the competence of the Polish customs authorities. The sovereignty in its normative sense means the possession of full powers in the scope of imposing customs duty as well as granting customs reliefs and exemptions. The essence of the sovereignty in its executive sense is, on the contrary, the fact that only state authorities are entitled to make decisive powers regarding customs duty in a certain area. The creation of structure of customs administration stays within the individual competence of member states. The only requirement is creating a body that would be able to implement acquis communautarie and cooperate with customs administrations of other member states.

While discussing the reform of customs system one should first of all think of the meaning of a customs system. The EU Customs Code defines customs authorities in a very general way - it says that they are authorities entitled, among other things, to use the regulations of customs law $^{2}$. Before the accession of Poland to the EU the Director of the Customs Office and the President of the Central Customs Office used to be considered as customs authorities. In the course of preparations to the accession to the EU the President of the Central Customs Office lost his position as the main customs authority in the Polish administration and his competence was taken over, pursuant to the Act on transformations in the customs administration, including amendments to some acts, dated 20 March 2002, by the competent Minister of Public Finance and by the directors of customs chambers ${ }^{3}$. As a result

\footnotetext{
1 Compare The judgement of the European Court of Justice of 15 June 1999, case CV-394/97, Sami Heinonen v. Helsingin karrajaoikeus, H. Sylwestrowicz, E. Kalisiak, C. Wernic, Wspólnotowy i narodowy system zwolnień celnych, Szczecin 2005, p. 143.

2 Art. 4.3 Council Regulation (EEC) No 2913/92 of 12 October 1992 establishing the Community Customs Code, OJ L 302 of 19.10 .1992$.

3 Dz. U. Nr 41, poz. 365 z 2002r. z późn. zm.
} 
of transformations, carried out in 2002, a new three-level structure of customs administration was created ${ }^{4}$ :

- the main level of the Polish customs administration consists of the heads of customs offices along with the respective offices,

- the second level consists of the directors of customs chambers along with the respective chambers,

- the third level is the Minister of Finance along with the respective office ${ }^{5}$.

The customs offices that existed before 30 April 2002 were transformed into customs chambers as bodies which accompanied the directors of customs chambers, and some of the customs divisions were transformed into customs offices as bodies accompanying new authorities in the structure of customs administration i.e. the heads of customs offices. As a result of the implemented changes 17 customs chambers and 67 customs offices were created ${ }^{6}$. Customs Divisions are subordinate to Customs Offices, and the units of customs administrations called the customs stations were liquidated. A similar, three-level structure of administration, in the scope of customs matters, may also be found in other member states of the EU, that is, in Germany, Austria, France, Italy, Lithuania and Latvia.

Under the 20 May 2003 Act on Formation of Voivodeship Boards of Revenue and including amendments to some acts (which established tasks, the authorities' competences and the organization of organizational units subordinate to the competent minister of public finance) the so far competent authorities (revenue offices and chambers) lost their competence in the scope of excise tax. The role of tax authority in this scope and partially in the sphere of goods and services tax, was passed onto customs authorities ${ }^{7}$. The act came into force on 1 September 2003. Hence, these authorities play a double role - the one of customs authorities, and some of them (although not all) simultaneously act as tax authorities.

It may be stated that the customs administration is undergoing a continuous reform. In 1999 the Customs Service Act was passed, which was meant to adapt that formation to function as a public service in the EU. It sets special requirements to the candidates for customs officers and to people already working as such officers. The

$4 \quad$ Ustawa z dnia 20 marca 2002r. o przekształceniach w administracji celnej oraz o zmianie niektórych ustaw (Dz. U. Nr 41 poz. 365 z 2002r.)

5 In S. Naruszewicz's opinion Minister of Finance cannot be considered as one of customs authorities. S. Naruszewicz, Wspólnotowe prawo celne, Warszawa 2004, p. 68.

6 Under the 9 April 2004 Ordinance of Minister of Finance (w sprawie utworzenia izb celnych i urzędów celnych oraz określenia ich siedzib) the number of customs chambers was decreased to 14, and customs offices -to 52. (Dz. U. Nr 82, poz. 747 z 2004r.)

7 Art. 11 ustawy z dnia 20 maja 2003r., o utworzeniu wojewódzkich kolegiów skarbowych (Dz. U. Nr 137, poz. 1302 z 2003 r.) See E. Giska, Przebudowa aparatu skarbowego, „Monitor Prawa Celnego” Nr 8, 2003, s. 345 and E. Giska, Dyrektor izby celnej i naczelnik urzędu celnego organami podatkowymi (część druga) „Monitor Prawa Celnego", Nr 9, 2003, s. 392. 
public aspect of customs service is the fact that the actions of customs officers create the respect towards state authorities and trust on the side of the citizens. The official relationships of uniformed services are not of employment nature, but they are administrative relationships created when an officer starts his service. The specific nature of the uniformed service means, among other things, full availability for work and obedience towards the authorities, discipline when being on duty, fulfilling tasks within the unlimited time and in difficult conditions (which sometimes pose risk to health or life $^{8}$ ) limited participation in political life, no possibility of a strike, prohibition to run own business, statutory limitation in having additional place of employment etc.

In January 2008 Poland faced a wave of protests made by the officers of Customs Service. Pursuant to Art. 33 Section 2 of the Customs Service Act, a customs officer must not participate in a strike or any activity that disturbs the work of a customs office. Due to that, customs officers used to go on sick leaves or asked their superiors for a day off to which they are entitled to, pursuant to the Labour Code. That spontaneous protest action of customs officers was caused, among other things, by the regulations included in the Customs Service Act, namely Art. 25 Section 1 Points $8 \mathrm{a}$ and $8 \mathrm{~b}$ of that Act. This regulation introduced obligatory dismissal of a customs officer from his/her service in the case of a charge of deliberate commission of an indictable offence brought against him/her, or in the case of provisional detention. The General Trade Union of Customs Service in Poland questioned the above regulation stating, among other things, that it limits rights and freedom of officers in the way that is not justified in a democratic state. Furthermore, it states that the provisions do not include the possibility of restoration of a customs officer dismissed on the basis of an objective regulation on conditional discontinuance of criminal proceedings and on discontinuance of criminal proceedings ${ }^{9}$. The Constitutional Tribunal decided in its 13 February 2007 Judgment that the objective regulation is in accordance with the Constitution. In particular, it referred to the General Public Prosecutor's standpoint that the special rigours of customs service are compensated to the officers by granting them special retirement and pension entitlements. The paradox is that customs officers, as the only one uniformed service, are not covered by a retirement plan of uniformed services. In practice, Art. 25 Section 1 (8a) and (8b) of the Customs Service Act has started to be used by smugglers to intimidate customs officers.

8 The examination conducted at the border crossing points with the Kaliningrad Oblast has proved that about $70 \%$ of customs officers faced the threat of battery or denunciation of taking bribes, which pursuant to Art. 25 Section 1 Points $8 \mathrm{a}$ and $8 \mathrm{~b}$ of the Customs Service Act, was equal to a dismissal from the service. A few officers were beaten up by unknown delinquents. See M. Kęskrawiec, „Monitor Prawa Celnego i Podatkowego” Nr 2, 2008, s. 65.

9 See wyrok TK $z$ dnia 13 lutego 2007r., sygn. akt K 46/2005, System informacji prawnej LEX-Administracja Skarbowa nr 245355. 
Another reason for the protest was a proposal made in the project of the KAS Act regarding the implementation of the so called zero option, that is, the dissolution of employment relationship with all customs officers and then re-appointment only some of them. Although the zero option is justified in the case of territorial selfgovernment reform, it is an unsuccessful idea with reference to customs officers. The employer remains the same. Specific identified problems in the Customs Service should be fought with, and not only seemingly eliminated through the so called zero options. One-time action will not eliminate the phenomenon of corruption. Only creating mechanisms which would detect unfavourable phenomena will permanently clear the customs officers' environment from the so called 'black sheep'. The zero option will, on the contrary, strike both the corrupted customs officers and the honest ones. Another reason for a 'strike' is unequal treatment of customs officers in comparison with other uniformed services. Due to the liquidation of border crossing points in the South and West in 2004, the so called allocation of customs officers from the western border crossing points and inland organization units to customs chambers in the East of Poland took place. However, in December 2007 after our accession to the Schengen zone, the similar mechanism was not implemented in the case of the Border Guard with its many more officers. Such an unequal treatment of customs officers in comparison with other uniformed services may result from the fact that customs officers are commonly associated with a profession of negative emotional connotation and a very negative opinion in the social consciousness ${ }^{10}$. A new function of the customs service as a formation protecting the society against terrorism, drugs, epidemiological threats remains totally unnoticed.

In the course of the protest there were proposals to replace the Polish customs officers with the ones from other member states of the EU. It has to be categorically emphasized that there are no regulations that would allow to employ foreign citizens to protect the state. The on-duty acts on behalf of the Polish state may be performed within the territory of Poland exclusively by the customs officers who have the Polish citizenship $^{11}$. The rule of exercising sovereign superior rights in the range of customs and protection of the Polish customs territory as a part of the EU customs territory is best guaranteed by performing customs service by its own citizens exclusively. As a matter of fact, the Ordinance of the Minister of Finance of 28 April 2004 was binding within the period from 1 May 2004 to 4 February 2005, which regarded the adaptation period and ability test in the course of proceedings regarding recognition of qualifications to perform the profession of a customs officer, acquired in member states of the $\mathrm{EU}^{12}$. It enabled customs officers of other member states to acquire suwerennych praw państwa i ochrona praw obywatelskich, „Państwo i Prawo” z. 1, 1970, s. 18.

Dz. U. Nr 101, poz. 1033 z 2004r. 
recognition of professional qualifications, and thus to serve at the Customs Service in Poland. However, that regulation was inconsistent with the act of higher importance, that is, the Customs Service Act of 24 July 1999 which in its Art. 2 stipulates that such service may be performed by a Polish citizen ${ }^{13}$. In practice the above regulation was 'dead law' as no customs officer moved to the Polish Customs Service from another member state. The above regulation was annulled by the Regulation of the Minister of Finance of 11 January $2005^{14}$.

As a result of the protest action the customs administration obtained pay rise in the amount of 244,45 Polish zlotys from the budget act and 245,55 Polish zlotys from the reserve fund no. 60, which gave total amount of 499 Polish zlotys for an employee $^{15}$. From the statement made by the Chief of the Customs Service on 27 March 2008 on the forum of the Board of Administration and Internal Affairs and the Board of Public Finance it appears that the average salary in the Customs Service at its lower positions is higher than the one in the Border Guard. Why then do customs officers organize a protest action if they earn more than the Border Guard officers? It should be emphasized that a Border Guard officer is automatically promoted after the statutory period onto a higher position which includes pay rise, whereas many people in the Customs Service remain on the same position for a several dozen years, in spite of their high qualifications. It is closely associated with dramatic resignation of people from work in the Customs Service. At some border crossing points the newly admitted officers make only $30-40 \%$ of the staff. The customs officers who remain in the preparatory service are not entitled to serve goods movement and therefore the Customs Service may shortly face the problem of staff shortage, especially due to the fact that the number of crossing points at the eastern borders does not meet the needs of the border movement. Even if the customs officers do not organize protests, the queues at the border crossing points are up to a few dozen hours.

The customs officer is a hybrid of a uniformed public officer and a civil worker - s/he pays social insurance contributions in the same way as all civil workers do, but his/her sick leaves are of full remuneration whereas the ones of civil workers are only $80 \%$ of the total remuneration. S/he is not entitled to receive the uniformed retirement benefit, although s/he performs his/her duties wearing a uniform, and it has to be highlighted that $\mathrm{s} / \mathrm{he}$ may be released from this obligation by his/her superior only in justified circumstances. In case of accidents and diseases connected with his/her service the customs officer is entitled to benefits that are established for the police officers. Comparing retirement benefits of the Rail Protection Service, which

\footnotetext{
13 Tekst jedn.: Dz. U. Nr 156, poz. 1641 z 2004r.

14 Rozporządzenie Ministra Finansów z dnia 11 stycznia 2005r. uchylające rozporządzenie w sprawie stażu adaptacyjnego i testu umiejętności w toku postępowania w sprawie uznania nabytych w państwach członkowskich Unii Europejskiej kwalifikacji do wykonywania zawodu funkcjonariusza celnego (Dz. U. Nr 13, poz. 99 z 2005r.).

15 See Biuletyn Komisji Administracji i Spraw Wewnętrznych oraz Komisji Finansów Publicznych z posiedzenia z dnia 27 marca 2008r. Nr 445/VI kad., s. 5.
} 
may be treated as a state industrial guard, it seems that the refusal of uniformed benefits to customs officers is an unjustified discrimination of this occupational group. The division of persons employed in the customs administration into civil service and customs service, where there is no division into persons performing duties provided by the statute and representing public authority - and the persons who contribute to functioning of a particular organization unit, is not essentially justified. The people perform the same work in the same organization units, but are paid totally different salary. A border officer or a policeman working at his/her desk does not lose uniformed benefits if the activities performed by such people are fulfilled as duties provided by the Police Act or the Border Guard Act. Only in the Police, the positions where the duties are not directly related to performing statutory tasks of the particular service (like human resources, payments department, logistics or general departments) are treated as civil ones. As far as acting on behalf of the state is concerned, the public officer is supported by the authority of his/ her uniform which emphasizes the power that $\mathrm{s} / \mathrm{he}$ performs on behalf of the state. Moreover, such a person has to be distinguished in order to be easily identified by the citizens, which makes the public service more recognizable and signals clearly to the citizens that this person serves the society. The division in the customs system may be organized in a similar way with the emphasis on enabling the customs officers to change the customs service into the civil one. Performing customs service is dependent on meeting certain special requirements which, with the lapse of time, may not be fulfilled, either temporarily or permanently, by the officer, e.g. in cases of disability that does not entitle to disability benefit, or lack of full flexibility to work irregular hours for single parents who bring up minor children.

A fundamental question should now be raised - in what direction does the reform of the Customs Service go? The reform of the Customs Services aims at improving the effectiveness of its service towards the society. With regard to high rotation of staff the officers should obviously be ensured the salary at such a level that would make them resistant to corruption, but it would also be beneficial to organize psychological training courses on how to cope with corruption offers.

The draft of an act on the amendment to the Customs Service Act and on amendments to some acts of 14 March 2008 imposed new requirements on the customs officers ${ }^{16}$. Many solutions included in the draft of the act bring the Customs Service closer to uniformed services, e.g. possibility to move staff between uniformed services and the Customs Service, the establishment of similar ranks and bodies, legal protection, or bonuses for performing duties in special conditions. In the sphere of competence it grants the Customs Service entitlements to operational obliged to be at permanent availability of his superior. 
and reconnaissance activities as well as the right to possess personal weapon. In the face of drafted amendments and imposing new obligations and restrictions on the customs officers, the Customs Service is explicitly becoming a service of requirements imposed on the uniformed services.

With the application of the restrictions typical for uniformed formations, the customs officers are simultaneously refused the privileges which should compensate the inconveniences resulting from serving the society. Furthermore, if the state imposes greater requirements on the customs officers, it should itself act loyally towards them. On the other hand, mechanisms fighting negative phenomena should be created for the Customs Service, and that could be e.g. granting the control services powers to use provocation towards those officers who are suspected of corruption. One of the best solutions that would ensure the officers' resistance to corruptive factors would be the introduction of state retirement, lost in the case of proving the officer gaining the financial benefit related to the function performed. 


\section{Streszczenie}

Problemy związane z reformą systemu celnego w Polsce można podzielić na dwie grupy: pierwsza związana jest z przebudową administracji skarbowej, druga odnosi się do pozycji celników jako urzędników służby cywilnej. W rezulatcie zmian przyjetych w 2002 r. wprowadzono trójpoziomową strukturę polskiej administracji celnej:

- główny poziom objemuje naczelników urzędów celnych razem $\mathrm{z}$ odpowiednimi urzędami,

- drugi poziom składa się z dyrektorów izb celnych razem z odpowiednimi izbami,

- trzeci poziom jest tworzony przez ministra finansów razem z kierowanym przez niego ministerstwem.

Od 2003 r. organy celne odgrywają podwójną rolę - z jednej są właściwe w sprawach z zakresu prawa celnego, z drugiej - jednocześnie są organami podatkowymi (choć nie wszystkie). 